\title{
Challenges for Social Policy in a Less Favorable Macroeconomic Context
}

\author{
Suzanne Duryea, Andrew Morrison, Carmen Pagés, Ferdinando Regalia, \\ Norbert Schady, Emiliana Vegas, and Héctor Salazar
}

Over the last decade and a half Latin America and the Caribbean have made notable advances in reducing poverty and improving social outcomes. Extreme poverty fell by more than a third from $19.3 \%$ in 2002 to $12.0 \%$ in $2014 ;^{1}$ and inequality, as measured by the Gini coefficient, fell from 0.56 to $0.51 .^{2}$ In parallel, child mortality fell from 32 to 18 deaths per 100,000 children from 2000 to 2013 (see UN IGME 2014). By 2013, school attendance rates among 6-11-year-olds reached $98 \%$, and among 12-17-year-olds rose to $87 \% .^{3}$ Although gaps remain across income and demographic groups, the biggest advances in reducing chronic malnutrition and improving school age-attendance profiles occurred for children from the lowest socioeconomic groups.

Many of these gains were fueled by the substantive increase in public expenditure. As can be seen in Fig. 1, from 2000 to 2012 overall social spending increased at a much faster rate than GDP; indeed, over this period the share of social spending in GDP rose from $14 \%$ to almost $19 \%$ of GDP. Rapid increases in GDP per capita also directly contributed to improving social outcomes. Decompositions of the reduction in inequality attribute between a third and a half to the higher labor income of the poor associated with faster growth (Levy and Schady 2013). This report suggests that these two channels for improved social outcomes-rapid increases in

\footnotetext{
Previously published as Chapter "Macroeconomic Challenges for Social Policy" of the monograph "The Labyrinth: How Latin America and the Caribbean can Navigate the Global Economy," IDB, 2015. The authors thank Santiago Levy for his numerous suggestions.
}

${ }^{1}$ ECLAC (2014). The poverty rate for 2014 was predicted.

${ }^{2}$ Population-weighted calculations from IDB-harmonized household surveys for the period 2003-2013.

${ }^{3}$ IDB/SCL-harmonized household surveys - 16 countries with data 2000-2013, weighted population average.

S. Duryea $(\square) \bullet$ A. Morrison $\bullet$ C. Pagés $\bullet$ F. Regalia $\bullet$ N. Schady $\bullet$ E. Vegas $\bullet$ H. Salazar Social Sector, Inter-American Development Bank, Washington, DC 20577, USA e-mail: suzanned@iadb.org 


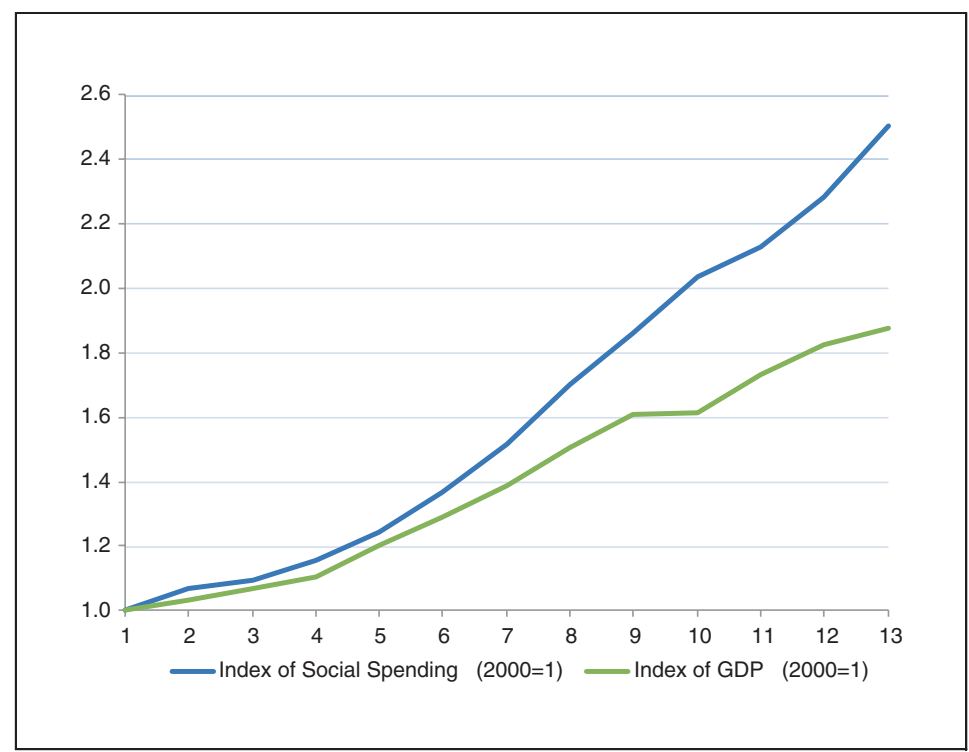

Source: ECLAC (2014) and IMF (2014). Population weighted for countries with spending and GDP data.

Fig. 1 Latin American and Caribbean social spending and GDP 2000-2012. Source: ECLAC (2014) and IMF (2014). Population weighted for countries with spending and GDP data

social expenditures and high rates of growth-may be less favorable in coming years. The increasingly constrained fiscal space faced by most countries, combined with a possible protracted period of lower growth, indicates that the recent pace of increases in social spending is unlikely to be sustainable in the coming years. While there is heterogeneity across countries, many are likely to face pressure to accomplish more with similar or lower levels of resources.

In this context, it is essential to avoid undercutting recent gains in social outcomes. In fact, it appears that progress in reducing poverty has already stalled. Deploying policies to consolidate and increase social gains is of the essence. More precisely, the region faces two challenges: (1) ensuring that the less favorable macroeconomic environment does not translate into increased inequality and poverty, and (2) designing social policies that help raise productivity and accelerate mediumterm growth. Despite their best intentions, social policies that are not aligned with productivity will set Latin America and the Caribbean on a path to lower welfare. Smarter social spending needs to be a key response to the challenging scenario of protracted low growth - by promoting better functioning labor markets, encouraging human capital accumulation, helping workers to be more effective in their jobs, and, ultimately, closing productivity gaps with other regions.

This chapter addresses how aspects of social policy in the areas of labor markets and social insurance, poverty programs, health, and education can be designed to 
protect the important social gains achieved, and better position the region for longrun growth. The discussion focuses on three areas:

- Improve efficiency with a focus on quality

- Promote income stability and protection without distorting workers' incentives

- Exercise caution with respect to creating potentially costly and irreversible commitments

\section{Improve Efficiency with a Focus on Quality}

In Latin America and the Caribbean there is ample space to improve the efficiency of spending and accomplish more with a similar amount of resources. In sectors such as health, social protection, labor training, and education, service quality remains the key challenge to be addressed.

\subsection{Health}

Health systems in the region face pressure from population aging, rising chronic diseases, demand to expand coverage, and adoption of technological advances. In a fiscally constrained scenario the priority is to adopt policies to increase technical and allocative efficiency without sacrificing coverage and quality. Policies should focus on two areas: (1) spending better, and (2) shifting more resources toward preventive services.

An analysis of 191 countries found that Latin America and the Caribbean are between 12 and 44 percentage points below the most efficient countries in producing healthy life expectancy -Evans et al. (2001). Marinho et al. (2012) reveal large discrepancies in returns on investment in the countries of the region expressed in indicators such as life expectancy, infant survival rate, and years of life recovered from communicable and noncommunicable diseases and external causes. Inefficiencies relate to human resources, health technology and drugs, organization of providers, misuse of resources, and inappropriate intervention packages.

Measures for improving efficiency include (1) closing gaps between planning and budget allocation by implementing strategic purchasing or value-for-money approaches, in which health financing decisions are based on explicit prioritization criteria, evidence of the cost-effectiveness of interventions, and provider quality and efficiency, and (2) providing incentives for productivity, quality, and innovation through payment mechanisms such as result-based financing.

On the other hand, implementation of preventive services - key to reducing the rate of growth of health spending and containing the increasing incidence of chronic diseases - is at an incipient stage in the region. An IDB survey of regional users that replicates a methodology applied in OECD countries found that only $31-52 \%$ of 


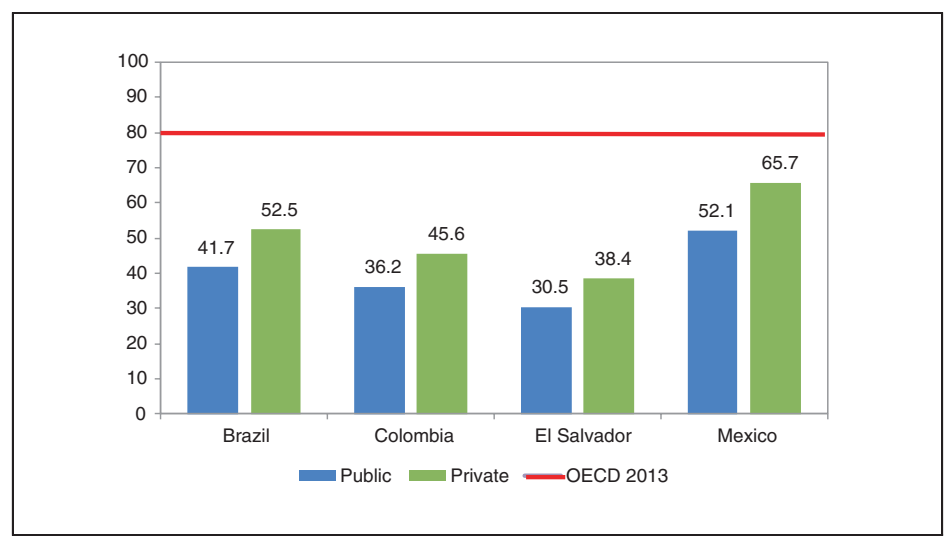

Source: Guanais et al., forthcoming. OECD is average of 11 OECD countries in International Health Policy Survey.

Fig. 2 Percentage of population up to date in preventive health measures. Source: Guanais et al. (forthcoming). OECD is average of 11 OECD countries in International Health Policy Survey

users of public health services in countries surveyed reported being up to date on a minimum set of preventive health measures, in contrast to an average of $80 \%$ in OECD countries (see Fig. 2 and Guanais et al. forthcoming). In seven countries in the region it was estimated that $20 \%$ of hospitalizations could be avoided with good primary care (Guanais et al. 2012). Strengthening the response capacity and quality of early care levels, as a gateway to the health system, can reduce the need for complex and expensive services (OECD 2010; Smith 2012).

\subsection{Social Protection: Conditional Cash Transfer Programs}

Since the 1990s, when cash transfers were complemented with co-responsibility mechanisms to encourage human capital accumulation, conditional cash transfer programs (CCTs) have expanded rapidly in the region. In 2010 approximately 129 million individuals in 18 countries in Latin America and the Caribbean-24\% of the population-were receiving transfers that represented on average 20-25\% of family income. CCTs have been effective in reducing the incidence and especially the intensity of poverty. They have also improved school attendance and reduced child labor, contributing to school progression (see Levy 2006; Fiszbein et al. 2009; Saavedra and Garcia 2012). And they have promoted the use of health services and reduced mortality for specific age groups (Gaarder et al. 2010; Rasella et al. 2013).

However, at least three issues need to be addressed. First, expansion of coverage has led to more benefits being received by the extreme nonpoor, while the coverage of the extreme poor is below universal. Thus, although in general CCTs have achieved better targeting than previous programs, there are ongoing challenges of 


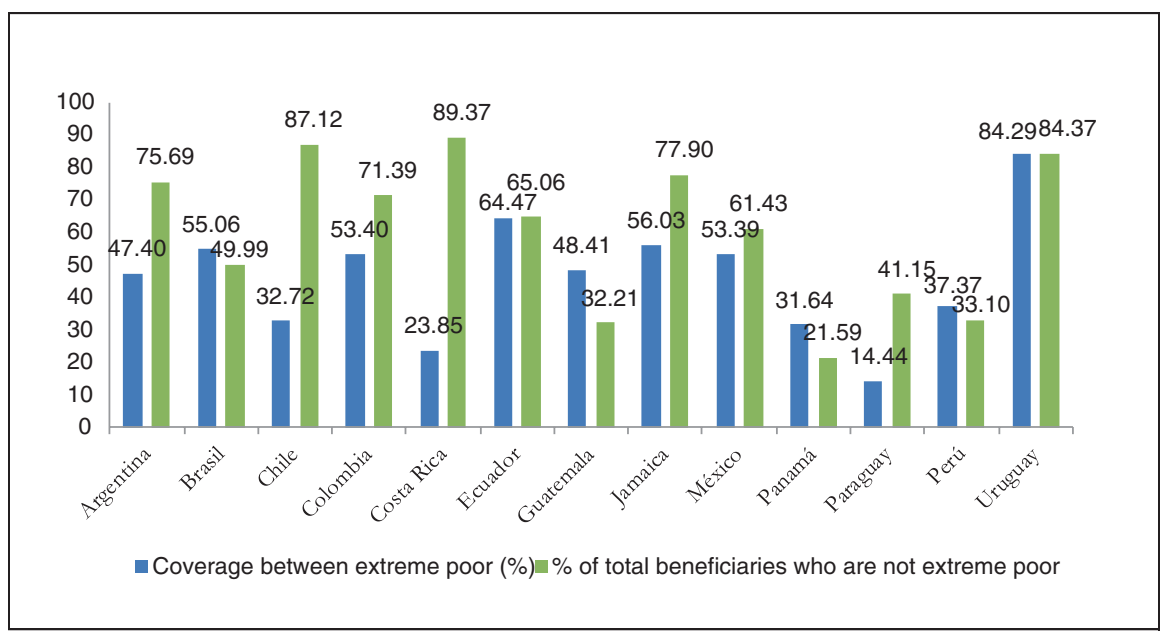

Source: Stampini and Tornarolli (2012)

Fig. 3 Conditional cash transfer programs in Latin America and the Caribbean. Source: Stampini and Tornarolli (2012)

program leakage and under-coverage, as shown in Fig. 3 and Stampini and Tornarolli (2012). To maintain their effectiveness as a tool to combat poverty, CCTs should prioritize targeting the poorest groups, particularly in rural areas where poverty is chronic.

Second, in several countries the real value of transfers, measured as a percentage of household income beneficiaries, has increased to $40 \%$ of household income (Stampini and Tornarolli 2012; Levy and Schady 2013). Transfer levels should be reasonably modest in magnitude (no higher than 20-25\% of average household income of beneficiaries before the transfer). Increases in transfer levels should be carefully considered in the context of the potential for negative incentives for labor supply. Finally, in some countries benefits have been made contingent on the form of workers' participation in the labor market, in particular on their informal status. This has led to incentives to remain informal, which is detrimental to workers' own income and the economy's productivity.

\subsection{Training}

Labor productivity is partly determined by the skills that an employee brings to the job and how these skills are used by the firm. Decades of poor educational policies have left the region with a stock of workers with relatively low skills, a major bottleneck both for the adoption of new technologies and the productive use of existing ones. Investing in workers can raise labor productivity and with it the potential for 
economic growth (Bassanini et al. 2005). Training may be particularly relevant during economic slowdowns, when the opportunity cost is lower.

All countries in the region implement labor taxes to finance training for workers, ranging from $0.25 \%$ in Uruguay to $3 \%$ of the total payroll in Jamaica. However, in many cases there is little or no information on returns and accountability is lacking. A recent IDB study finds that on-the-job training appears to raise productivity, but only in the case of large firms. A one percentage point increase in the proportion of trained employees raises productivity by $0.8 \%$ in firms of more than 100 employees (Flores Lima et al. 2014). The study also shows that the vast majority of firms selffinance their training rather than using public resources. Only 14-19\% of firms reported using public funds for training purposes in the last 3 years while 78-94\% reported using self-financing. ${ }^{4}$ This underscores the need to revise the coverage, targeting, and relevance of the public tools that support on-the-job training in the region.

A greater impact could be achieved by investing these resources in (1) developing mechanisms to align training with the needs of companies and workers; (2) improving the quality of training offered; and (3) establishing systems for monitoring and evaluation. An improvement in the quality of training would promote productivity gains, and potentially reduce job loss.

\subsection{Education}

During the last three decades, Latin America and the Caribbean have achieved enormous progress in school enrollment. Some countries in the region also saw modest progress in student learning. However, students from Latin America and the Caribbean continue to perform in the bottom quartile in the distribution of student test scores in most international assessments, notably the most recent Programme of International Student Assessment (PISA). In PISA 2012, the performance of students in the seven countries participating from the Latin American and Caribbean region was among the bottom 14 out of 65 countries (Bos et al. 2014).

Poor performance in terms of quality contrasts with budgetary outlays. Spending on education has risen from 4.2\% of GDP in 2000 to $5.6 \%$ in 2013 (ECLAC 2014). Yet there is no consistent evidence that spending on inputs such as physical infrastructure, classroom technology, flexible education funding grants, or smaller class sizes improves students' learning outcomes. The effectiveness of teachers is the main lever to improve student learning and mounting evidence indicates that the performance of teachers in classrooms and the quality of teacher-student interactions determine learning outcomes (Hamre et al. 2014; Araujo et al. 2014). To improve the quality of teaching, the region may wish to consider (1) introducing selective processes to recruit the most talented individuals into the teaching profession, and (2) strengthening

\footnotetext{
${ }^{4}$ The range represents the difference between the average of small and large firms. In other words, $14 \%$ of small firms reported using public resources for training activities compared to $19 \%$ of large firms.
} 
mechanisms to motivate teachers to perform at their best, including ongoing professional development and support as well as instruments to reward teacher excellence. These factors need not imply more spending, but rather better targeted spending.

In parallel, demographic trends in relation to students and teachers present an opportunity for efficiency gains. On the one hand, the overall composition of students will continue to shift away from primary school; on the other, approximately one-sixth of the teaching force will reach retirement age over the next 5 years. It will be important to monitor population shifts to plan appropriate class sizes, and deploy newly recruited teachers where needed and with the right skills. Given these changes, opportunities exist in some countries to reallocate spending more efficiently by merging classes, schools, and/or school districts.

In order to identify these opportunities prospective expenditure monitoring requires strengthening various education data management systems (including censuses of students, teachers, schools, and student learning assessments). In turn, this will require institutional strengthening of education offices at all levels.

\section{Promote Income Stability and Protection Without Distorting Workers' Incentives}

There are understandable incentives, particularly during economic downturns to extend the coverage of social insurance, and to protect workers against income loss. However, some such policies may inadvertently become permanent and may be detrimental to long-run growth. This section discusses policy options that are compatible with promoting income stability while maintaining incentives for participation in the formal sector to increase long-run productivity.

\subsection{Improve Protection for Job Loss}

In general, the region has a precarious and truncated system of protection against job loss that increases the costs of downturns and impedes automatic income stabilization. Almost all countries in Latin America and the Caribbean have mandatory severance pay, but only 8 provide unemployment insurance (11 if those including obligatory individual savings accounts are included). However, these instruments are only available to a select group of formal salaried workers, which constitute only $42 \%$ of the workforce. ${ }^{5}$ So, for most workers, there is no preestablished unemployment protection mechanism.

\footnotetext{
${ }^{5}$ Mean for 19 countries in 2013, from IDB Labor Market and Social Security System of Indicators. The figure represents the proportion of formal salaried workers in relation to the total active population (employed and unemployed workers).
} 
Under a severance system, the lump-sum payment paid to a dismissed formal worker accumulates over time, and is only due in case of unjust dismissal, providing firms with incentives to shorten job tenure below optimal levels or enter into litigation regarding the cause for separation. A severance pay scheme may also generate distortions by encouraging firms to hire permanent workers under temporary contracts, which has been shown to reduce productivity (Dolado and Stucchi 2008). There is considerable scope to improve the coverage and design of employment protection instruments toward those that enhance long-run productivity such as unemployment insurance, and away from those like severance pay that can inadvertently hinder productivity and discourage the creation of formal employment.

Unemployment insurance can help families smooth income loss while providing consistent incentives for workers and firms with respect to on-the-job training and the retention of experienced, productive workers. A reform of severance policies would lower the labor cost associated with uncertainty arising from the high degree of litigiousness, which in turn would promote more formal employment of longer duration. The increase in formal employment contracts of indefinite duration would have the added benefit of improving the coverage of contributory pension and health programs, providing more fiscal space in the long run. In turn, more formality and a lower degree of temporary employment would generate productivity gains.

For formal workers, there are advantages to moving away from a standard severance pay instrument to a mixed instrument that includes compensation, in case of dismissal or layoff as well as individual accounts, funded by companies (and possibly workers) that would be available to the worker in case of voluntary resignation or dismissal. The pre-savings will improve the effectiveness of the instrument, particularly in economic downturns.

A complementary action would be to strengthen public employment services so that unemployment insurance and severance pay/individual accounts can be linked with active policies for training and job placement. Programs can be integrated through "single windows," which consolidate services and provide synergies to job seekers with the ultimate objective to achieve rapid and effective reintegration of workers.

In the event of a crisis, temporary employment programs (TEP) or public works are often aimed at workers without certification and/or very low skills. These can be effective in providing protection for income loss for informal workers, but they should be careful not to detract from laying the groundwork for effective systems of protection in the long term, that is, from promoting formality. It is also important to learn from past experience with TEPs: design projects that are straightforward to implement, minimizing administrative costs so that the bulk of the resources reach the workers, and set a low transfer level that incentivizes the self-targeting of labor supply (entry and exit of work). 


\subsection{Reduce Labor Taxes to Promote Formal Sector Jobs}

As reviewed in Powell (2015), raising taxes may not be the most appropriate form of fiscal adjustment. This is particularly true for labor taxes that tend to promote informality. Indeed, there is a negative relationship between the cost of labor and the rate of formal job creation, and while this elasticity varies from country to country, it is clear that higher taxes on labor can lead to a destruction of formal employment (Bosch et al. 2013). As described in the 2014 Latin American and Caribbean Macroeconomic Report, lowering labor taxes may enhance productivity and medium-term growth in part by reducing informality.

\subsection{Promote Female Labor Force Participation}

Enhancing female participation in the labor force may also enhance productivity as well as promote gender equality and increase income per capita. Estimates from the region indicate that the loss from low female participation ranges from $3.4 \%$ of GDP in the case of Mexico to $17 \%$ of GDP for Honduras (Mateo Díaz and Rodíguez-Chamussy 2015). Estimates for OECD countries include $5 \%$ of GDP for the USA and $9 \%$ of GDP for Japan (Elborgh-Woytek et al. 2013). Although Latin America and the Caribbean are the regions experiencing the highest growth in female labor force participation in the world (increasing from $49 \%$ in 2000 to $54 \%$ in 2013), participation levels for women still lag behind those in East Asia and the Pacific (54\% against $63 \%$ for 2013). Younger cohorts of women are achieving similar or higher levels of educational attainment than men in most countries of the region. Investing in quality childcare and after-school programs, promoting flexible job arrangements, and revising labor and social insurance legislation to ensure equal treatment of women can lower barriers and, in turn, further promote labor insertion.

\section{Exercise Caution with Respect to Creating Potentially Costly and Irreversible Commitments}

As recognized by various authors (Duryea et al. 2009), measures considered by policymakers as temporary may, due to political economy reasons, become very difficult to change, thus creating irreversible commitments. Moreover, some such policies may be extremely costly, especially considering the demographic changes facing the region. This section discusses some selected policies that are particularly vulnerable in this regard. 


\subsection{Minimum Wage Policies}

Minimum wages continue to grow in real terms in Latin America and the Caribbean, generating important gains for some workers. However, minimum wages also generate losers: those who cannot find formal employment, or any employment, given the higher labor costs associated with the minimum wage. A substantial proportion of the salaried workforce receives wages below the minimum in the region, ranging from $15 \%$ to $17 \%$ in Mexico and Uruguay, respectively, to $61 \%$ and $74 \%$ in Guatemala and Honduras. These figures increase as the level of the minimum wage increases in relation to the average wage. As such, it is important to exercise caution before raising the level of the minimum wage to avoid increasing unemployment and reducing formal employment, both of which hurt long-term growth and productivity, to the detriment of workers themselves.

\subsection{Adjustment Mechanisms and Levels for Noncontributory Pensions}

Only four in ten adults aged 65 and older receive a contributory pension in Latin America and the Caribbean. Low coverage of contributory pensions has led to a rapid expansion of so-called noncontributory pensions (NCPs), even though, of course, in the end somebody must pay. This has allowed coverage of older adults receiving a pension to expand. All countries have instituted some form or other of an NCP to address poverty in old age. Taking both together, the proportion of older adults who receive a pension increases from four to six out of ten, and the number of people receiving an NCP continues to increase rapidly in the region.

While this is positive from the point of view of poverty reduction, if appropriate measures are not taken, NCPs may become unsustainable from a fiscal and economic perspective. This reflects both the weight of demographic trends and the incentives to refrain from contributing to pensions that NCPs can generate. In the next 35 years, the proportion of adults aged 65 and over will increase from 7 to $20 \%$ of the total population. In light of this change in the age structure, fiscal costs of NCP will triple. It is therefore important to establish measures to safeguard their sustainability. As can be seen in Fig. 4, considerable heterogeneity currently exists across countries in the transfer level of NCP. While among eight countries the total cost of NCP is currently less than $0.5 \%$ of GDP, in Bolivia expenditures are more than double that at over $1 \%$ of GDP. If the current pension is adjusted in real terms, current spending on NCP will pass from approximately $1 \%$ in Bolivia and rural Brazil to over 2 or $3 \%$ of GDP by 2050 (Bosch et al. 2013). In this context, it is critical to design automatic adjustment mechanisms and strong institutions capable of safeguarding the amount of pensions against short-term pressures associated with the political process. 


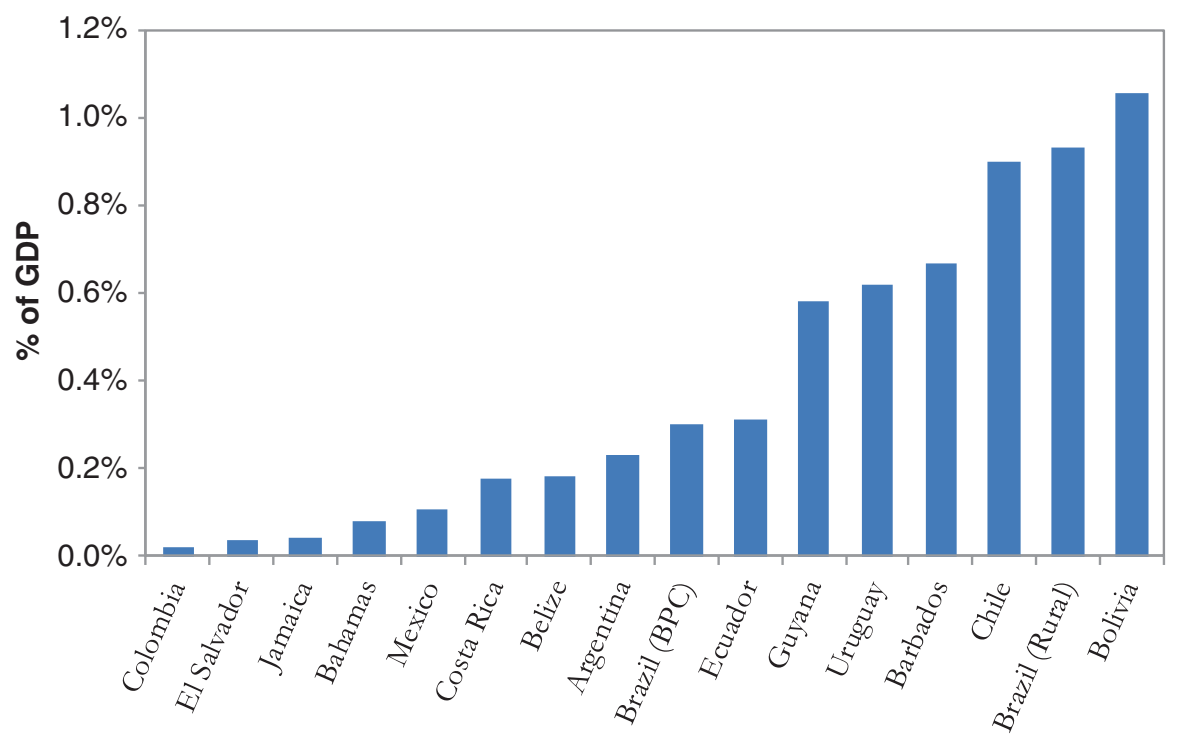

Source : Bosch, Melguizo and Pagés (2013).

Fig. 4 Public spending on noncontributory pensions in 2012 (percentage of GDP). Source: Bosch et al. (2013)

In addition, if they are not designed correctly, NCPs can produce undesirable incentives. This is particularly the case when eligibility for an NCP is limited to individuals who do not have a contributory pension; this can provide a disincentive to participate in contributory pensions, and increase informality, which is clearly undesirable from the point of view of productivity. More broadly, it is important to integrate the noncontributory and contributory pension pillars and seek to increase the coverage of the contributory system. Mutatis mutandis, similar remarks can be made of noncontributory health insurance programs.

Open Access This chapter is distributed under the terms of the Creative Commons Attribution 4.0 International License (http://creativecommons.org/licenses/by/4.0/), which permits use, duplication, adaptation, distribution and reproduction in any medium or format, as long as you give appropriate credit to the original author(s) and the source, a link is provided to the Creative Commons license and indicate if changes were made.

The images or other third party material in this chapter are included in the work's Creative Commons license, unless indicated otherwise in the credit line; if such material is not included in the work's Creative Commons license and the respective action is not permitted by statutory regulation, users will need to obtain permission from the license holder to duplicate, adapt or reproduce the material.

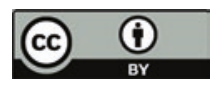




\section{References}

Araujo, M.C., Carneiro, P., Cruz-Aguayo, Y., \& Schady, N. (2014, October). A helping hand? Teacher quality and learning outcomes in kindergarten, Working Paper.

Bassanini, A. Booth, A. L., Brunello, G., de Paola, M., \& Leuven, E. (2005). Workplace training in Europe. IZA Discussion Paper. No 1640. Bonn.

Bos, M. S., Ganimian, A. J., \& Vegas, E. (2014). Brief \#5: ¿Cómo se desempeñan los varones y las mujeres? Serie de Briefs-América Latina en PISA 2012. Washington, DC and Paris, France: Inter-American Development Bank and Organisation for Economic Co-operation and Development.

Bosch, M., Melguizo, Á., \& Pages, C. (2013). Better pensions, better jobs: Towards universal coverage in Latin America and the Caribbean. Washington, DC: Inter-American Development Bank.

Dolado, J. J., \& Stucchi, R. (2008). Do temporary employment contracts affect TFP? Evidence from Spanish manufacturing firms. IZA Discussion Paper No. 3832. Bonn.

Duryea, S., Mazza, J., \& Regalia, F. (2009). Social and labor market policies for tumultuous times: Confronting the global crisis in Latin America and the Caribbean. Washington, DC: InterAmerican Development Bank.

ECLAC (Economic Commission for Latin America and the Caribbean) (2014, December). Social Panorama of Latin America 2014. Flagships.

Elborgh-Woytek, K., Newiak, M., Kochhar, K., Fabrizio, S., Kpodar, K., Wingender, P., et al. (2013). Women, work, and the economy: Macroeconomic gains from gender equity. IMF Staff Discussion Notes No. 13/10.

Evans, D. B., Tandon, A., Murray, C. J. L., \& Lauer, J. A. (2001). The comparative efficiency of National Health Systems in producing health. GPE Discussion Paper Series No. 29. EIP/GPE/ EQC, World Health Organization.

Fiszbein, A., Schady, N. R., \& Ferreira, F. H. (2009). Conditional cash transfers: reducing present and future poverty. World Bank Publications.

Flores Lima, R., Gonzalez-Velosa, C., \& Rosas Shady, D. (2014). Five facts about labor training in firms in Latin America and the Caribbean. Washington, DC: Inter American Development Bank (in Spanish).

Gaarder, M. M., Glassman, A., \& Todd, J. E. (2010). Conditional cash transfers and health: Unpacking the causal chain. Journal of Development Effectiveness, 2(1), 6-50.

Guanais, F. C., Gómez-Suárez, R., \& Pinzón, L. (2012). Series of avoidable hospitalizations and strengthening primary care. En Publicación, BID.

Guanais, F. C., Macinko, J., Mullachery, P., \& Jiménez, G. (Forthcoming). Results from the IDB Survey on Primary Health Care and Health System Performance in Latin America and the Caribbean. IDB working paper. Inter-American Development Bank, Washington, DC.

Hamre, B., Hatfield, B., Pianta, R., \& Jamil, F. (2014). Evidence for general and domain-specific elements of teacher-child interactions: Associations with preschool children's development. Child Development, 85(3), 1257-1274.

IMF (International Monetary Fund) (2014). World Economic Outlook Database.

Levy, S. (2006). Pobreza y transición democrática en México: La continuidad de ProgresaOportunidades. Fondo de Cultura Económica (FCE).

Levy, S., \& Schady, N. (2013). Latin America's social policy challenge: Education, social insurance, redistribution. The Journal of Economic Perspectives, 27(2), 193-218.

Marinho, A., Cardoso, S. D. S., \& Almeida, V. V. D. (2012). Avaliação de Eficiência em Sistemas de Saúde: Brasil, América Latina, Caribe y OCDE. Texto para Discussão 1784. Rio de Janeiro: Instituto de Pesquisa Econômica Aplicada.

Mateo Díaz, M., \& Rodíguez-Chamussy, L. (2015). Cashing in on education: Women, childcare, and prosperity in Latin America and the Caribbean. Unpublished manuscript. 
OECD (2010). Health care systems: Getting more value for money. OECD Economics Department Policy Notes, No. 2. Smith, Peter C. 2009. Measuring value for money in healthcare: Concepts and tools. London: The Health Foundation.

Paes-Sousa, R., Regalia, F., \& Stampini, M. (2013). Condiciones para el éxito de la puesta en práctica de programas de transferencias monetarias condicionadas: lecciones de América Latina y el Caribe para Asia.

Powell, A. (Coord.). (2015). The labyrinth: How can Latin America and the Caribbean navigate the global economy. Washington: Inter-American Development Bank.

Rasella, D., Aquino, R., Santos, C. A., Paes-Sousa, R., \& Barreto, M. L. (2013). Effect of a conditional cash transfer programme on childhood mortality: A nationwide analysis of Brazilian municipalities. The Lancet, 382(9886), 57-64.

Saavedra, J. E., \& Garcia, S. (2012). Impacts of conditional cash transfer programs on educational outcomes in developing countries: A meta-analysis. RAND labor and population working paper WR-921-1. Santa Monica, Calif.: Rand.

Smith, P. C. (2012). What is the scope of health system efficiency gains and how can they be achieved? Eurohealth, 18(3), 3-6.

Stampini, M., \& Tornarolli, L. (2012). The growth of conditional cash transfers in Latin America and the Caribbean: Did they go too far? (No. 49). IZA Policy Paper.

UN Inter-Agency Group (2014). Levels and trends in child mortality. Report 2014. Estimates Developed by the UN Inter-agency Group for Child Mortality.

Suzanne Duryea is a Principal Research Economist in the Social Sector of the Inter-American Development Bank where her work focuses on youth development in Latin America and the Caribbean. Prior to joining the Social Sector, she worked as a Senior Economist in the Research Department of the IDB. Her publications have appeared in peer-reviewed journals such as Journal of Development Economics, Journal of Human Resources, and American Economic Journal: Applied Economics. She is a research affiliate at the Population Studies Center at the University of Michigan and a member of the executive committee of the Latin American and Caribbean Economic Association (LACEA). She holds a Ph.D. in economics from the University of Michigan. 